Revista Eletrônica de Direito Processual - REDP.

Rio de Janeiro. Ano 10. Volume 17. Número 2. Julho a Dezembro de 2016

Periódico Semestral da Pós-Graduação Stricto Sensu em Direito Processual da UERJ

Patrono: José Carlos Barbosa Moreira. ISSN 1982-7636. pp. 266-297 www.redp.uerj.br

\title{
OS LIMITES SUBJETIVOS DA COISA JULGADA COLETIVA, AS \\ IMPROPRIEDADES DO ARTIGO 16 DA LEI 7.347/85 E A POSSIBILIDADE DE \\ UMA FUTURA MUDANÇA NA JURISPRUDÊNCIA DO STJ À LUZ DA TÉCNICA DO JULGAMENTO-ALERTA ${ }^{1}$
}

\author{
THE SUBJECTIVE LIMITS OF THE RES JUDICATA IN BRAZILIAN CLASS \\ ACTIONS, THE INADEQUACIES OF ARTICLE 16 OF THE ACT 7,347/85 AND \\ THE POSSIBILITY OF A FUTURE CHANGE IN THE STJ CASE-LAW ON BASIS \\ OF THE JUDGMENT-ALERT TECHNIQUE.
}

Gustavo Silva Alves

\begin{abstract}
Mestrando em Direito pela Universidade Federal do Espírito Santo. Participante do Grupo de Pesquisa Processo Coletivo: Modelo Brasileiro liderado pelos professores Hermes Zaneti Jr. e Antonio Gidi.. Advogado. gugalves2003@gmail.com
\end{abstract}

RESUMO: O presente trabalho possui o escopo de abordar, no âmbito do direito processual coletivo, a coisa julgada, com enfoque para seus limites subjetivos. Pretende-se também realizar uma análise das impropriedades previstas no artigo 16 da Lei 7.347/85, demonstrando a possibilidade de uma futura mudança da jurisprudência pátria no que diz respeito à aplicabilidade do artigo 16 da Lei 7.347/85 à luz da técnica do julgamento-alerta.

PALAVRAS-CHAVE: Coisa Julgada; Limites Subjetivos; Competência; Processo Coletivo; Julgamento-Alerta.

ABSTRACT: This paper has the scope to study, within the collective procedural law, the res judicata, focusing on its subjective limits as well proceed an analysis of the improprieties referred in the article $16^{\circ}$ of Law $n^{\circ} 7.347 / 85$ and finally demonstrate the possibility of future change of jurisprudence regarding the applicability of Article 16 of Law 7.347 / 85 in the light of the judgment-alert technique.

\footnotetext{
${ }^{1}$ Artigo recebido em 15/12/2015 e aprovado em 18/04/2016.
} 
Revista Eletrônica de Direito Processual - REDP.

Rio de Janeiro. Ano 10. Volume 17. Número 2. Julho a Dezembro de 2016

Periódico Semestral da Pós-Graduação Stricto Sensu em Direito Processual da UERJ

Patrono: José Carlos Barbosa Moreira. ISSN 1982-7636. pp. 266-297 www.redp.uerj.br

KEYWORDS: Res judicata; Subjective Limits; Competence; Class Actions; JudgementAlert.

SUMÁRIO: 1. Introdução; 2. Breves comentários aos direitos metaindividuais previstos no Código de Defesa do Consumidor. 3. A coisa julgada coletiva e a problemática dos limites de sua extensão subjetiva; 3.1 A coisa julgada coletiva e sua sistemática no microssistema da tutela coletiva; 3.2 A controversa alteração do artigo 16 da lei da ação civil pública (7.347/85) trazida pela MP 1.570/97 (convertida na Lei 9.494/97); 4. As críticas doutrinárias e as impropriedades do artigo 16 da LACP alterado pela MP 1.570/97; 4.1 O Processo Coletivo Brasileiro e a Indivisibilidade do Objeto da Tutela Coletiva; 4.2. Equívoco de Técnica Legislativa. Teoria Geral do Processo. Confusão entre as noções de jurisdição, competência e limites subjetivos da res judiciata. Regramento Específico quanto a Competência (art. 93 do CDC); 4.3 As Inconstitucionalidades formal e material da alteração normativa e sua ofensa a diversos Princípios do Ordenamento Jurídico Brasileiro; 5. Uma possível futura mudança do entendimento por parte do STJ à luz da Técnica do Julgamento-Alerta; 5.1. Conciso Histórico do Posicionamento Jurisprudencial em relação ao art. 16 da Lei 7.437/85; 5.2. A Técnica do Julgamento-Alerta nos países de civil law; 5.3. A análise do REsp $\mathrm{n}^{\circ}$ 1.114.035/PR à luz da técnica do julgamento-alerta e a possibilidade/necessidade de futura mudança na Jurisprudência do STJ quanto a aplicabilidade do artigo 16 da Lei 7.347/85; 6. Conclusão.

\section{Introdução}

Pretende-se examinar no presente trabalho o instituto da coisa julgada nos processos coletivos, com enfoque para sua extensão subjetiva. Tal instituto processual, como outros, teve de sofrer adaptações para se adequar a realidade e natureza dos direitos coletivos lato sensu.

A partir dessa análise, destaca-se a alteração legislativa do artigo 16 da Lei 7.347/85, a qual ocorreu por meio da MP 1.570/97 (convertida na Lei $\mathrm{n}^{\circ}$ 9.494/97) e pretendeu restringir a coisa julgada coletiva à competência territorial do órgão julgador.

Demonstrar-se-á que tal alteração gerou diversas impropriedades e críticas doutrinárias ao dispositivo normativo em questão. Tomando como parâmetro para análise, 
Revista Eletrônica de Direito Processual - REDP.

Rio de Janeiro. Ano 10. Volume 17. Número 2. Julho a Dezembro de 2016

Periódico Semestral da Pós-Graduação Stricto Sensu em Direito Processual da UERJ

Patrono: José Carlos Barbosa Moreira. ISSN 1982-7636. pp. 266-297

www.redp.uerj.br

o Microssistema da Tutela Coletiva, a Teoria Geral do Processo e também a Constituição Federal.

Em sequência, optando-se por uma metodologia de pesquisa jurisprudencial, será apresentado breve histórico da temática nos Tribunais Superiores, com destaque para o recente julgado REsp 1.114.035/RS, o qual será analisado à luz da técnica do julgamentoalerta.

Isso com intuito de se demonstrar a futura possibilidade de mudança no entendimento da Corte Especial no julgamento dos Embargos de Divergência no REsp n ${ }^{\circ}$ $1.243 .386 / \mathrm{RS}$

2. Breves comentários aos direitos metaindividuais previstos no Código de Defesa do Consumidor.

Como cediço o ordenamento jurídico pátrio, após a promulgação da Constituição Federal de 1988, reconheceu a existência dos direitos coletivos lato sensu. Posteriormente, estes foram conceituados no Código de Defesa do Consumidor - Lei nº 8.078/90 (CDC).

Dessa forma, para um melhor entendimento da tutela coletiva no direito brasileiro, é imprescindível que se compreenda cada um das espécies de direitos metaindividuais previsto no Código de Defesa do Consumidor.

No parágrafo único do artigo 81 do CDC, é feita a subdivisão dos direitos coletivos lato sensu em suas respectivas espécies: direitos difusos, direitos coletivos stricto sensu e direitos individuais homogêneos, vejamos:

"Art. 81. A defesa dos interesses e direitos dos consumidores e das vítimas poderá ser exercida em juízo individualmente, ou a título coletivo.

Parágrafo único. A defesa coletiva será exercida quando se tratar de:

I - interesses ou direitos difusos, assim entendidos, para efeitos deste código, os transindividuais, de natureza indivisível, de que sejam titulares pessoas indeterminadas e ligadas por circunstâncias de fato; 
Revista Eletrônica de Direito Processual - REDP.

Rio de Janeiro. Ano 10. Volume 17. Número 2. Julho a Dezembro de 2016

Periódico Semestral da Pós-Graduação Stricto Sensu em Direito Processual da UERJ

Patrono: José Carlos Barbosa Moreira. ISSN 1982-7636. pp. 266-297

WWW.redp.uerj.br

II - interesses ou direitos coletivos, assim entendidos, para efeitos deste código, os transindividuais, de natureza indivisível de que seja titular grupo, categoria ou classe de pessoas ligadas entre si ou com a parte contrária por uma relação jurídica base;

III - interesses ou direitos individuais homogêneos, assim entendidos os decorrentes de origem comum" (grifo nosso).

Primeiramente, no inciso I, têm-se os direitos difusos, que são transindividuais (ultrapassam a esfera individual), de natureza indivisível (são considerados como um todo, possuindo objeto indivisível), tendo como titulares, pessoas indeterminadas ligadas por um circunstâncias de fato e não de direito.

Como exemplo de ofensa a direito difuso, podemos citar a divulgação nos meios midiáticos de uma propaganda enganosa e abusiva ${ }^{2}$.

Já no inciso II foram conceituados os chamados direitos coletivos stricto sensu. Tais direitos foram classificados como transindividuais (no mesmo sentido dos direitos difusos), de natureza indivisível (objeto indivisível), sendo seus titulares, grupo, categoria ou classe de pessoas ligadas entre si ou com a parte contrária por uma relação jurídica base.

Quanto à titularidade dos direitos coletivos stricto sensu, vale destacar que seus titulares são indetermináveis, porém, determináveis enquanto grupo, categoria ou classe ${ }^{3}$.

Nessa esteira, é importante salientar que a relação jurídica pode se dar entre os membros do grupo (affectio socciattis) ou por ligação com a parte contrária ${ }^{4}$. Como exemplo da primeira situação temos os Advogados inscritos na Ordem dos Advogados do Brasil, já na segunda, podemos citar os estudantes de uma mesma escola pública, os quais tem ligação com o Ente Político responsável pela Escola.

\footnotetext{
${ }^{2}$ DIDIER JR., Freddie Souza; ZANETI JR., Hermes. Curso de Direito Processual Civil. $9^{\mathrm{a}}$ ed. Salvador: JusPodivm, 2014. v. 4, p. 69.

${ }^{3}$ Ibidem, p. 69.

${ }^{4}$ Sobre a motivação que levou o legislador a prever a possibilidade de relação jurídica base por ligação com a parte contrária, Marcelo Abelha Rodrigues faz brilhante apontamento: "A preocupação do legislador em estender a proteção ao grupo de pessoas que não possuam vínculo entre si, mas, sim, com a parte contrária, decorre do fato de que, não sendo obrigatório o associativismo (liberdade pública), é possível que mesmo a pessoa não sendo associada a uma categoria, ainda assim, seja titular de um direito coletivo, pelo simples fato de que possui, como o associado, uma relação jurídica base com a parte contrária" (RODRIGUES, Marcelo Abelha. Coord. LENZA, Pedro. Direito Ambiental Esquematizado. $2^{\mathrm{a}}$ ed. São Paulo: Saraiva, 2015, p. 41).
} 
Revista Eletrônica de Direito Processual - REDP.

Rio de Janeiro. Ano 10. Volume 17. Número 2. Julho a Dezembro de 2016

Periódico Semestral da Pós-Graduação Stricto Sensu em Direito Processual da UERJ

Patrono: José Carlos Barbosa Moreira. ISSN 1982-7636. pp. 266-297

www.redp.uerj.br

Outrossim, é necessário que essa relação jurídica base seja estabelecida antes da ofensa ao direito coletivo stricto sensu, ou seja, existe um caráter de anterioridade no que diz respeito a formação da jurídica base em relação à lesão ao direito.

Finalmente, no inciso III, está prevista outra espécie de direito coletivo, denominado de direitos individuais homogêneos. Assim, os DIH são aqueles decorrentes de origem comum $^{5}$, ou seja, são aquelas situações em que a relação jurídica entre as partes é decorrente da própria lesão sofrida pelos indivíduos.

Tais direitos tem em comum sua gênesis, que é a conduta omissiva ou comissiva da parte contrária. Nesta estão presentes questões de fato ou de direito que lhe conferem certo grau de homogeneidade ${ }^{6}$.

Deve ser destacado também, assim como apontam Hermes Zaneti Jr. e Freddie Didie Jr., que os direitos individuais homogêneos necessitam ser considerados como uma espécie de direito coletivo propriamente dito ${ }^{7}$.

Diferentemente do que entende a doutrina majoritária ${ }^{8}$, a qual classifica esses direitos como acidentalmente coletivos, acreditamos que a tutela dos DIH não se restringe aos direitos individuais.

Ao prescrever a fluid recovery no artigo 100 do $\mathrm{CDC}^{9}$ se esta tutelando a coletividade atingida pelo dano causado, para que assim, este não venha novamente a ocorrer.

\footnotetext{
${ }^{5}$ Para conferir concretude e evitar equívocos, é importantíssimo que conceituemos a expressão "origem comum", nesse contexto, Kazuo Watanabe afirma: “'Origem Comum' não significa, necessariamente, uma unidade factual e temporal. As vítimas de uma publicidade enganosa veiculada por vários órgãos de imprensa e em repetidos dias ou de um produto nocivo á saúde adquirido por vários consumidores em um largo espaço de tempo, e em várias regiões têm, como causa de seus danos, fatos com homogeneidade tal que os tornam "origem comum de cada um deles" (GRINOVER, Ada Pelegrini; WATANABE, Kazuo; NERY JR., Nelson. Código de Defesa do Consumidor: comentado pelos autores do anteprojeto. $10^{\mathrm{a}}$ ed. São Paulo: Forense Universitária, 2011, vol. 1, p. 629).

${ }^{6}$ DIDIER JR.; ZANETI JR., op. cit., p. 70.

${ }^{7}$ Ibidem, p. 74.

${ }^{8}$ Nesse sentido: RODRIGUES, op. cit., p. 44-45; ZAVASCKI, Teori Albino. Processo Coletivo: tutela de direitos coletivos e tutela coletiva de direitos. São Paulo: Revista dos Tribunais 2006; MOREIRA, José Barbosa. As ações coletivas na Constituição Federal de 1988. In: MILARĖ, Edis. A ação civil pública: após 25 anos. São Paulo. Revista dos Tribunais, 2010, p. 363-365.

9 "Art. 100. Decorrido o prazo de um ano sem habilitação de interessados em número compatível com a gravidade do dano, poderão os legitimados do art. 82 promover a liquidação e execução da indenização devida; Parágrafo único. O produto da indenização devida reverterá para o fundo criado pela Lei $n .{ }^{\circ} 7.347$, de 24 de julho de 1985". Entende-se como fluid recovery a possibilidade de complementação da indenização devida pela causadora do dano. Somente no caso de o valor pago após o período de um ano de habilitação dos interessados não representar a gravidade do dano causado.
} 
Revista Eletrônica de Direito Processual - REDP.

Rio de Janeiro. Ano 10. Volume 17. Número 2. Julho a Dezembro de 2016

Periódico Semestral da Pós-Graduação Stricto Sensu em Direito Processual da UERJ

Patrono: José Carlos Barbosa Moreira. ISSN 1982-7636. pp. 266-297

www.redp.uerj.br

Prevendo tal possibilidade o legislador está resguardando o interesse da

coletividade, mesmo que na ação coletiva estejam sendo tratados direitos individuais decorrentes de uma origem comum.

Feita essa breve exposição sobre as espécies de direitos coletivos presentes no ordenamento jurídico brasileiro, podemos avançar na problemática do presente trabalho, analisando, para tanto, o instituto da coisa julgada coletiva.

\section{A coisa Julgada Coletiva e a problemática dos limites de sua extensão subjetiva.}

\subsection{A Coisa Julgada Coletiva e sua sistemática no Microssistema da Tutela Coletiva.}

Analisando o ordenamento jurídico brasileiro quanto à tutela dos direitos coletivos, mais precisamente quanto à coisa julgada ${ }^{10}$, temos diversas legislações especiais regulando o assunto.

Nesse ponto, ganham destaque: a Lei Popular (Lei 4.717/65), Lei da Ação Civil Pública (Lei 7.347/85) e, principalmente, o Código de Defesa do Consumidor (Lei 8.078/90).

Tais legislações em conjunto com outras também pertinentes aos direitos transindividuais (Lei de Improbidade Administrativa, Lei do Mandado de Segurança Coletivo e etc.) formam o denominado Microssistema do Processo Coletivo, cuja existência, inclusive, já foi reconhecida pelo Superior Tribunal de Justiça (STJ) ${ }^{11}$.

Esse microssistema tem como característica principal e especial, a interpenetração entre as diversas legislações que o formam. Tal fato possibilita uma reunião intercomunicante não somente das regras gerais, como ocorre na maioria dos

\footnotetext{
${ }^{10}$ Considerado por Antônio Gidi como um dos institutos mais importantes do processo coletivo, pois, é a coisa julgada que confere a tutela coletiva sua devida amplitude, ao prescrever a extensão subjetiva erga omnes e ultra partes. (GIDI, Antônio. Rumo a um código de processo civil coletivo: a codificação das ações coletivas do Brasil. Rio de Janeiro: GZ Editora. 2008, p. 278).

11 "A lei de improbidade administrativa, juntamente com a lei da ação civil pública, da ação popular, do mandado de segurança coletivo, do Código de Defesa do Consumidor e do Estatuto da Criança e do Adolescente e do Idoso, compõem um microssistema de tutela dos interesses transindividuais e sob esse enfoque interdisciplinar, interpenetram-se e subsidiam-se [...]". (STJ - Resp n ${ }^{\circ}$ 510.150/MA, $1^{\text {a }}$ T., Rel. Min. Luiz Fux, j. 17.2.2004.).
} 
Revista Eletrônica de Direito Processual - REDP.

Rio de Janeiro. Ano 10. Volume 17. Número 2. Julho a Dezembro de 2016

Periódico Semestral da Pós-Graduação Stricto Sensu em Direito Processual da UERJ

Patrono: José Carlos Barbosa Moreira. ISSN 1982-7636. pp. 266-297

www.redp.uerj.br

microssistemas, mas também de regras e institutos específicos ${ }^{12}$, como é o caso da coisa julgada.

Assim, vejamos o disposto no artigo 103 do CDC, o qual funciona como regra geral do microssistema da tutela coletiva ${ }^{13}$ no que diz respeito à coisa julgada:

Art. 103. Nas ações coletivas de que trata este código, a sentença fará coisa julgada:

I - erga omnes, exceto se o pedido for julgado improcedente por insuficiência de provas, hipótese em que qualquer legitimado poderá intentar outra ação, com idêntico fundamento valendo-se de nova prova, na hipótese do inciso I do parágrafo único do art. 81;

II - ultra partes, mas limitadamente ao grupo, categoria ou classe, salvo improcedência por insuficiência de provas, nos termos do inciso anterior, quando se tratar da hipótese prevista no inciso II do parágrafo único do art. 81;

III - erga omnes, apenas no caso de procedência do pedido, para beneficiar todas as vítimas e seus sucessores, na hipótese do inciso III do parágrafo único do art. 81.

Para uma análise mais didática do artigo, devemos separá-lo de acordo com seus incisos, os quais tratam, individualmente, dos direitos difusos (CDC, Art. 103, I), direitos coletivos strictu sensu (CDC, Art. 103, II) e direitos individuais homogêneos (CDC, Art. 103, III).

Assim, quanto ao seu modo de produção, nas ações que versam sobre direitos difusos (inciso I) e coletivos (inciso II), estabeleceu-se a regra da coisa julgada secundum eventum probationis, aquela que se formará caso ocorra o esgotamento de provas.

\footnotetext{
${ }^{12}$ MAZZEI, Rodrigo Reis. A ação popular e o microssistema da tutela coletiva. In: DIDIER JR., Fredie Souza. MOUTA, José Henrique. MENDES, Aluisio Gonçalves de Castro. Tutela Jurisdicional Coletiva. Salvador: Juspodivm, 2009, p. 373-395.

13 "A disciplina comum das ações coletivas no Brasil encontra-se, portanto, estabelecida no Título III do CDC, que representa, por ora, o 'Código Brasileiro de Processos Coletivos'. Chega-se a essa conclusão, como foi visto, pela interpretação sistemática entre as regras do art. 21 da LACP e o do art. 90 do CDC." (DIDIER JR.; ZANETI JR., op. cit., p. 74). No mesmo sentido: (Gregório Assagra de. Direito Processual Coletivo Brasileiro: Um novo ramo do direito processual. São Paulo: Saraiva. 2003, p. 379).
} 
Revista Eletrônica de Direito Processual - REDP.

Rio de Janeiro. Ano 10. Volume 17. Número 2. Julho a Dezembro de 2016

Periódico Semestral da Pós-Graduação Stricto Sensu em Direito Processual da UERJ

Patrono: José Carlos Barbosa Moreira. ISSN 1982-7636. pp. 266-297

www.redp.uerj.br

Já para coisa julgada nos processos que versam sobre direitos individuais homogêneos (inciso III) não há uma regulamentação quanto à possibilidade aplicação da coisa julgada secundum eventum probationis.

Dessa forma, em que pese o entendimento da doutrina majoritária que adota uma interpretação literal do artigo $^{14}$, acreditamos ser mais adequado ao caso em tela a aplicação da mesma regra prevista nos incisos I e II, quanto aos direitos difusos e coletivos strictu sensu. Possibilitando-se também a revisão por prova nova, em caso de ter sido a causa julgada improcedente por insuficiência de provas.

As demandas decorrentes de direitos individuais homogêneos, como vimos, devem ser consideradas como verdadeiras ações coletivas e não como uma demanda individual tutelada coletivamente, pois esses direitos pertencem a um grupo fictício de indivíduos ${ }^{15}$.

Assim percebemos que, diferentemente do que grande maioria da doutrina processualista brasileira $\operatorname{adota}^{16}$, a coisa julgada coletiva é secundum eventum probationis e não secundum eventum litis (aquela que poderá se formar ou não dependendo do resultado do processo).

Isto porque, nas palavras de Antonio Gidi ${ }^{17}$, a coisa julgada somente será secundum eventum litis apenas quanto à sua extensão subjetiva, unicamente para beneficiar os titulares dos direitos individuais.

Já que, como sabemos os parágrafos $1^{\circ}, 2^{\circ}$ e $3^{\circ}$ do artigo 103 do $\mathrm{CDC}^{18}$ garantem proteção às pretensões individuais, no caso da ação coletiva ter sido julgada improcedente.

\footnotetext{
${ }^{14}$ Nesse sentido: LENZA, Pedro. Teoria Geral da Ação Civil Pública. São Paulo: Revista dos Tribunais, 2003, p. 286; GRINOVER, Ada Pelegri; WATANABE, Kazuo; NERY JR., Nelson. Código de Defesa do Consumidor: comentado pelos autores do anteprojeto. $10^{\mathrm{a}}$ ed. São Paulo: Forense Universitária, 2011, v. 2, p. 203.

${ }^{15}$ GIDI, Antônio. A Class Action como instrumento de tutela coletiva dos direitos: As ações coletivas e uma perspectiva comparada. São Paulo: Revista dos Tribunais, 2007, p. 286.

${ }^{16}$ Nessa esteira: LEONEL, Ricardo de Barros. Manual do processo coletivo. São Paulo: Revista dos Tribunais, 2002, p. 266; MANCUSO, Rodolfo de Camargo. Ação Civil Pública em defesa do meio ambiente, do patrimônio cultural e dos consumidores. $8^{\mathrm{a}}$ ed. São Paulo: Editora Revista dos Tribunais, 2002, p. 391; MAZZILI, Hugo Nigro. A Defesa dos Interesses Difusos em Juízo: meio ambiente, consumidor, patrimônio cultural, patrimônio público e outros interesses. $20^{\text {a }}$ Ed. São Paulo: Saraiva, 2007, p. 492/493.

${ }^{17}$ GIDI, Antônio. Coisa Julgada e Litispendência em Ações Coletivas. São Paulo: Saraiva, 1995, p. 73-74.

18 "Art. $103-[\ldots] \S 1^{\circ}$ Os efeitos da coisa julgada previstos nos incisos I e II não prejudicarão interesses e direitos individuais dos integrantes da coletividade, do grupo, categoria ou classe; $\S 2^{\circ}$ Na hipótese prevista no inciso III, em caso de improcedência do pedido, os interessados que não tiverem intervindo no processo como litisconsortes poderão propor ação de indenização a título individual; $\S 3^{\circ}$ Os efeitos da coisa julgada de que cuida o art. 16, combinado com o art. 13 da Lei $n^{\circ}$ 7.347, de 24 de julho de 1985, não prejudicarão as ações de indenização por danos pessoalmente sofridos, propostas individualmente ou na forma prevista neste código, mas, se procedente o pedido, beneficiarão as vítimas e seus sucessores, que poderão proceder à liquidação e à execução, nos termos dos arts. 96 a 99".
} 
Revista Eletrônica de Direito Processual - REDP.

Rio de Janeiro. Ano 10. Volume 17. Número 2. Julho a Dezembro de 2016

Periódico Semestral da Pós-Graduação Stricto Sensu em Direito Processual da UERJ

Patrono: José Carlos Barbosa Moreira. ISSN 1982-7636. pp. 266-297

www.redp.uerj.br

Continuando a tratar da extensão subjetiva da coisa julgada coletiva, que o bom entendimento é de extrema importância no presente trabalho, temos que nos direitos difusos (inciso I) e nos direitos individuais homogêneos (inciso III) optou-se pela coisa julgada erga omnes (aquela que atinge a todos - mesmo aqueles que não participaram do processo). Já nos direitos coletivos strictu sensu (inciso II) ela é ultra partes (atingindo não só as partes, mas também terceiros determinados).

Vale destacar, como lecionam Hermes Zaneti Jr. e Fredie Didier Jr. ${ }^{19}$ (2014, p. 338), que essa distinção entre erga omnes e ultra partes é um tanto quanto tênue, tratandose mais de um parâmetro legal adotado pelo legislador.

Conforme demonstram os doutrinadores, todo o grupo e seus membros serão atingidos, nos direitos difusos, um grupo composto por membros indetermináveis, nos direitos coletivos strictu sensu, um grupo composto por membros determináveis e nos direitos individuais homogêneos, um conjunto de vítimas indivisivelmente consideradas até liquidação e execução da sentença coletiva.

Percebemos dessa forma, que o legislador pátrio agiu de maneira acertada quanto a fixação da extensão subjetiva da coisa julgada. Pois, é da própria natureza do processo coletivo que a sentença atinja todos os titulares dos direitos coletivos lato sensu, caso contrário, estar-se-ia distorcendo seu objetivo precípuo, que é o da tutela uníssona em juízo desses direitos.

Entretanto, como veremos na sequência, tal sistemática ficou abalada, após a edição da Medida Provisória 1.570/97 (convertida na Lei 9.494/97), a qual culminou na polêmica alteração do artigo 16 da Lei da Ação Civil Pública (7.347/85).

\subsection{A controversa alteração do artigo 16 da Lei da Ação Civil Pública (7.347/85) trazida pela MP 1.570/97 (convertida na Lei 9.494/97).}

Sabe-se que o Brasil ainda é um país em desenvolvimento, com baixo nível educacional e com um dos maiores níveis de desigualdade socioeconômicos do mundo. Tal fato acaba por tornar o Poder Judiciário como responsável pela tutela das minguas da sociedade, quando o Estado não consegue efetivar todos os direitos da coletividade.

\footnotetext{
${ }^{19}$ DIDIER JR.; ZANETI JR., op. cit., p. 338.
} 
Revista Eletrônica de Direito Processual - REDP.

Rio de Janeiro. Ano 10. Volume 17. Número 2. Julho a Dezembro de 2016

Periódico Semestral da Pós-Graduação Stricto Sensu em Direito Processual da UERJ

Patrono: José Carlos Barbosa Moreira. ISSN 1982-7636. pp. 266-297

www.redp.uerj.br

Nesse ponto, as ações coletivas se tornaram um forte instrumento, tanto na tutela dos direitos coletivos quanto na fiscalização de atos do governo e possíveis abusos políticos. Essa importância ocorre, principalmente, devido à dimensão social das ações coletivas e também ao alcance da coisa julgada erga omnes ou ultra partes dessas demandas $^{20}$.

Assim, passado algum tempo da edição do Código de Defesa do Consumidor e da Lei da Ação Civil Pública, ou seja, após a consolidação do Microssistema do Processo Coletivo dentro do ordenamento jurídico brasileiro, começaram a surgir inúmeras ações coletivas no Poder Judiciário.

Em muitas dessas ações o Estado figurava no polo passivo, já que tratavam da tutela de direitos metaindividuais, os quais muitas vezes dependiam de sua atuação para que fossem efetivados.

Logo, tais demandas acabavam afetando o Governo, seja porque fiscalizavam seus atos ou porque requeriam a tutela de direitos coletivos. Diante disso, o Poder Público começou a se sentir acuado com a repercussão, dimensão e importância que as demandas coletivas alcançaram.

Podemos destacar, por exemplo, as diversas ações civis públicas que tinham como intuito impedir o Programa de Privatização do Setor de Telecomunicações da Administração Pública Federal, principalmente em relação à Telebrás e também outras que tratavam dos problemas salariais dos funcionários públicos federais ${ }^{21}$.

Dessa forma, conforme ensinamentos de Cássio Scarpinella Bueno ${ }^{22}$, o Estado tendo conhecimento de que fará parte de diversas ações judiciais, passa a tentar controlar o sistema de resolução de conflitos com o intuito de impedir, complicar, retardar ou neutralizar as pretensões da coletividade.

Foi nesse contexto político-jurídico que, na data de 22 de julho de 1997, o Governo Federal editou a Medida Provisória $n^{\circ} 1.570$, a qual em seu artigo $3^{\circ}$, alterou a redação do artigo 16 da Lei da Ação Civil Pública (7.347/85). Valendo destacar qual foi essa mudança:

\footnotetext{
${ }^{20}$ RODRIGUES, Marcelo Abelha. Ação Civil Pública e Meio Ambiente. Rio de Janeiro: Editora Forense Universitária, 2009, p. 253.

${ }^{21}$ LENZA, op. cit., p. 286.

${ }^{22}$ BUENO, Cássio Scarpinella. O Poder Público em Juízo. $2^{\mathrm{a}}$ ed. São Paulo: Saraiva, 2003, p. 218.
} 
Revista Eletrônica de Direito Processual - REDP.

Rio de Janeiro. Ano 10. Volume 17. Número 2. Julho a Dezembro de 2016

Periódico Semestral da Pós-Graduação Stricto Sensu em Direito Processual da UERJ

Patrono: José Carlos Barbosa Moreira. ISSN 1982-7636. pp. 266-297

www.redp.uerj.br

(Redação original) "art. 16. A sentença fará coisa julgada erga

omnes, exceto se a ação for julgada improcedente por deficiência de provas, hipótese em que qualquer legitimado poderá intentar outra ação com idêntico fundamento, valendo-se de nova prova." (grifo nosso).

(Redação atual) "art. 16. A sentença fará coisa julgada erga omnes nos limites da competência territorial do órgão prolator, exceto se a ação for julgada improcedente por deficiência de provas, hipótese em que qualquer legitimado poderá intentar outra ação com idêntico fundamento, valendo-se de nova prova." (grifo nosso).

Percebemos assim que, com o intuito de tentar frear a efetividade da tutela coletiva, restringindo os limites subjetivos da res judiciata coletiva à competência territorial do órgão prolator, edita-se a referida medida provisória ${ }^{23}$.

Outro ponto que merece relevo é o fato de que a MP 1.570/97 foi publicada com o intuito de disciplinar a tutela antecipada contra a Fazenda Pública, logo, a alteração do artigo 16 da Lei da LACP veio de maneira maliciosa e sorrateira em seu conteúdo.

Como já era de se esperar, essa modificação do artigo 16 da Lei no 7.347/85, resultou em duras críticas por parte da doutrina brasileira ${ }^{24}$.

Pontuaremos a seguir, quais foram os fundamentos utilizados nessas censuras e porque elas são extremantes pertinentes dentro de uma análise da Constituição Federal, da Teoria Geral do Processo e do Microssistema da Tutela Coletiva.

\section{As críticas doutrinárias e as impropriedades do artigo 16 da LACP alterado pela MP 1.570/97.}

\footnotetext{
${ }^{23}$ Essa Medida Provisória foi reeditada por cinco vezes para depois ser convertida na Lei no 9.494/97.

${ }^{24}$ Em celebre citação Marcelo Abelha conclui: "Se por um lado o art. 16 da LACP constitui um primor de um pensamento nefasto - de fazer inveja a Iago de Shakespeare ou a Dorian Gray de Oscar Wilde -, por outro é tecnicamente comparável às macaquices do exército de Brancaleone. Não há adjetivos técnicos para qualificar a péssima qualidade das modificações introduzidas no art. 16" (RODRIGUES, op. cit., p. 271).
} 
Revista Eletrônica de Direito Processual - REDP.

Rio de Janeiro. Ano 10. Volume 17. Número 2. Julho a Dezembro de 2016

Periódico Semestral da Pós-Graduação Stricto Sensu em Direito Processual da UERJ

Patrono: José Carlos Barbosa Moreira. ISSN 1982-7636. pp. 266-297

www.redp.uerj.br

\subsection{O Processo Coletivo Brasileiro e a Indivisibilidade do Objeto da Tutela Coletiva.}

Salta aos olhos em um primeiro momento, à luz do Microssistema do Processo Coletivo, que o legislador pátrio tentou cindir algo que é materialmente indivisível, seu objeto.

Indo contra toda a sistemática da tutela coletiva, que preconiza a indivisibilidade dos direitos coletivos lato sensu em juízo (artigo 81, parágrafo único do CDC), fracionouse algo que em sua origem é insétil.

Como apontam Marcelo Abelha Rodrigues e outros renomados juristas pátrios ${ }^{25}$ essa foi uma das grandes impropriedades da referida alteração normativa.

Além disso, como já destacado no início desse trabalho, o Código de Defesa do Consumidor em seu artigo 103, o qual regula a res judicata na tutela coletiva, não traz nenhuma forma de limitação quanto a extensão subjetiva da coisa julgada coletiva, determinando que esta alcançará todo o grupo e seus membros, sendo ultra partes ou erga omnes, a depender do direito coletivo tutelado.

É necessário compreender que o processo coletivo surgiu com intuito de dar proteção aos direitos transindividuais, os quais são resultado da nova atmosfera econômica e cultural em que vivemos.

Necessitou-se criar tal regramento para se proteger o meio ambiente, os consumidores e os patrimônios público e histórico etc., ou seja, para que fosse resguardado o interesse público primário ${ }^{26}$.

Negar a natureza do processo coletivo e aceitar essa limitação é ir em sentido contrário a todos os avanços que conseguimos alcançar nos últimos 30 anos no Estado Brasileiro, no que diz respeito a tutela coletiva em juízo.

Para confirmarmos todas essas afirmações, saímos do plano teórico e ingressamos no plano prático, citando diversos exemplos dados pela doutrina que confirmam a inocuidade da referida legislação.

25 “(...) Basta pensarmos que a imensa maioria dos direitos a serem tutelados por meio de ação civil pública são indivisíveis. Tal é, inclusive, a nota característica dos interesses essencialmente coletivos. E desta forma, o dispositivo tenta cindir aquilo que, por sua natureza é verdadeiramente incindível". (RODRIGUES, op. cit., p. 601); No mesmo sentido: LEONEL, op. cit, p. 259-260; DIDIER JR., ZANETI JR., op. cit., p. 131.

${ }^{26}$ CRUZ E TUCCI, José Rogério. Limites Subjetivos da Eficácia da Sentença e da Coisa Julgada nas ações coletivas. Doutrinas Essenciais de Processo Civil. vol. 9, p. 646, Out/2011. 
Revista Eletrônica de Direito Processual - REDP.

Rio de Janeiro. Ano 10. Volume 17. Número 2. Julho a Dezembro de 2016

Periódico Semestral da Pós-Graduação Stricto Sensu em Direito Processual da UERJ

Patrono: José Carlos Barbosa Moreira. ISSN 1982-7636. pp. 266-297

www.redp.uerj.br

Arenhart e Marinoni ${ }^{27}$ nos trazem o exemplo de uma ação coletiva proposta para impedir a construção de uma barragem em um determinado rio (que fica entre dois municípios, "X" e "Y"). Imaginemos que ela tenha sido proposta em ambos dos municípios, e que no município " $\mathrm{X}$ " o Juiz daquela comarca julgue procedente o pedido e no município "Y" a ação coletiva tenha sido julgada improcedente.

Respeitando o artigo 16 da Lei 7.347/85, como se resolveria a situação? Constrói-se a barragem até a metade do Rio? E se interpostos recursos contra essas sentenças? O processo que chegasse primeiro ao STF, órgão com competência nacional, por meio de Recurso Extraordinário prevaleceria sobre o outro?

Outro excelente exemplo nos é apresentado por Rodolfo de Camargo Mancuso ${ }^{28}$, imaginemos uma ação coletiva que tenha transitado em julgado no Estado do Rio Grande do Sul. Tal ação reconheceu o medicamento $\mathrm{X}$ como nocivo à saúde humana e determinou o dever de indenizar os consumidores lesados pela ingestão desse fármaco.

$\mathrm{O}$ dispositivo da sentença que determina "o medicamento $\mathrm{X}$ é nocivo à saúde humana" deve ter tratamento unitário, valendo para todas as pessoas em solo brasileiro que ingeriram o medicamento. Caso contrário, respeitando-se o atual teor do artigo 16 da Lei 7.347/85, possibilitaríamos a existência de uma saúde gaúcha, capixaba, mineira, baiana etc., o que seria um absurdo sem tamanho.

Assim, fica claro que, considerando a natureza indivisível do objeto da tutela coletiva e o Microssistema do Processo Coletivo, a regra prevista no artigo 16 da Lei 7.347/95 não pode prosperar. Deve ser desconsiderada qualquer tentativa de limitação da extensão subjetiva da coisa julgada coletiva presente em seu conteúdo.

Entretanto, como veremos a seguir, não foi somente nesse aspecto que o Presidente da República e o legislador pátrio pecaram ao realizar essa mudança normativa, também se confundiu as noções de competência e jurisdição com limites subjetivos da coisa julgada.

\subsection{Equívoco de Técnica Legislativa. Teoria Geral do Processo. Confusão entre as} noções de jurisdição e competência e limites subjetivos da res judiciata. Regramento Específico quanto a Competência (art. 93 do CDC).

\footnotetext{
${ }^{27}$ ARENHART, Sérgio Cruz; MARINONI, Luiz Guilherme. Manual do processo de Conhecimento. $3^{\mathrm{a}}$ ed. São Paulo: Revista dos Tribunais, 1995, p. 713-714.

${ }^{28}$ MANCUSO, op. cit., p. 166.
} 
Revista Eletrônica de Direito Processual - REDP.

Rio de Janeiro. Ano 10. Volume 17. Número 2. Julho a Dezembro de 2016

Periódico Semestral da Pós-Graduação Stricto Sensu em Direito Processual da UERJ

Patrono: José Carlos Barbosa Moreira. ISSN 1982-7636. pp. 266-297

www.redp.uerj.br

Antes de tratarmos do equívoco técnico presente no artigo 16 da Lei 7.347/85, no qual se confundiu jurisdição e competência com limites subjetivos da coisa julgada, devemos tecer breves comentários sobre cada um dos institutos em questão, para que posteriormente avancemos e compreendamos o grave erro cometido.

Assim, como nos leciona Eduardo José Couture ${ }^{29}$, influenciado pelas teorias de Chiovenda $^{30}$ e Carnelutti ${ }^{31}$, jurisdição é a função pública pela qual se determina o direito das partes com o intuito de dirimir a lide posta em juízo, mediante decisões que alcançam a coisa julgada, sendo aquela exercida por um Órgão Competente do Estado, conforme estabelecido em lei.

Como sabemos a jurisdição é una em todo o território nacional o que ocorre é uma distribuição entre os vários órgãos judiciários das atribuições relativas ao desempenho daquela.

Dá-se o nome de competência ao critério utilizado nessa distribuição. Dessa forma como nos ensina a tríade de doutrinadores em celebre obra, a competência é conceituada como medida de jurisdição ${ }^{32}$.

Dentre as diversas competências, faremos destaque, pela importância para o presente trabalho, à competência territorial, a qual é atribuída aos diversos órgãos jurisdicionais tomando como base a repartição do território brasileiro em circunscrições judiciárias.

\footnotetext{
${ }^{29}$ COUTURE, Eduardo José. Fundamentos Del Derecho Procesal Civil. $4^{\mathrm{a}}$ Ed. Buenos Aires: BdeF, 2007, p. 34.

${ }^{30}$ Para o jurista italiano a ideia de jurisdição estaria intimamente ligada a lei, a qual de forma abstrata e genérica regularia todos os casos concretos, sendo assim, a jurisdição seria a uma função estatal, na qual os órgãos públicos determinam a vontade concreta da Lei, substituindo assim a atividade de particulares. (CHIOVENDA, Giuseppe. Instituzioni di diritto processuale civile. Nápoles: Jovene, 1933. Trad. Port. De J. Guimarães Menegale. São Paulo: Editora Saraiva, 1965, nn. 137-141).

${ }^{31}$ Carnelluti diz que para que haja jurisdição deve existir uma justa composição da lide que a parte interessada deduz em juízo, assim, só haveria a atividade estatal da jurisdição caso existisse um conflito de interesses posto em juízo. (CARNELUTTI, Francesco. Diritto e processo. Nápoles: Morano, 1958, n. 12).

32 “(...) A jurisdição como expressão do poder estatal é uma só, não comportando divisões ou fragmentações: cada juiz, cada tribunal, é plenamente investido dela. Mas o exercício da jurisdição é distribuído, pela Constituição e pela Lei ordinária, entre os muitos órgãos jurisdicionais; cada qual então a exercerá dentre de determinados limites (...). Chama-se competência a quantidade de jurisdição cujo o exercício é atribuído a cada órgão ou grupo de órgãos." (CINTRA, Antônio Carlos de Araújo; GRINOVER, Ada Pellegrini; DINAMARCO, Cândido Rangel. Teoria Geral do Processo. 27ª ed. São Paulo: Malheiros, 2011, p. 251).
} 
Revista Eletrônica de Direito Processual - REDP.

Rio de Janeiro. Ano 10. Volume 17. Número 2. Julho a Dezembro de 2016

Periódico Semestral da Pós-Graduação Stricto Sensu em Direito Processual da UERJ

Patrono: José Carlos Barbosa Moreira. ISSN 1982-7636. pp. 266-297

www.redp.uerj.br

Analisando agora os limites subjetivos da coisa julgada, podemos afirmar que

estes determinam o número de pessoas a serem alcançadas pela força da coisa julgada em razão de determinada sentença imutável ${ }^{33}$.

Uma vez sedimentados esses conceitos, podemos analisar o grave erro cometido no artigo 16 da Lei 7.347/85. Trata-se aqui da falta de técnica do legislador, geradora de uma confusão entre os conceitos de competência territorial e limites subjetivos da coisa julgada. Como vimos acima, são institutos totalmente independentes e diversos, não podendo existir nenhuma relação entre ambos.

Dizemos isso, pois, não há como tentar limitar a eficácia da coisa julgada coletiva à competência territorial do órgão prolator da decisão. $\mathrm{O}$ alcance subjetivo da coisa julgada coletiva não é determinado pela competência territorial, aquele é assunto tratado no artigo 103 do CDC.

Dessa forma, uma vez proferida sentença em ação coletiva, essa irá produzir efeitos erga omnes ou ultra partes, em todo o território nacional, pois como vimos a jurisdição é una, não existe limitação territorial em razão de competência. O que a competência faz é distribuir essa jurisdição entre os diversos órgãos jurisdicionais ${ }^{34}$.

Portanto, o que quis o legislador foi fragmentar a decisão em sede ação coletiva, entretanto, para isso, utilizou-se de instituto equivocado, qual seja, a competência territorial.

\footnotetext{
${ }^{33}$ Como vimos, a res judicata coletiva, no que diz respeito aos limites subjetivos, pode ser ultra partes ou erga omnes, dependendo do direito coletivo tutelado, sempre sendo todo o grupo alcançado, valendo destacar também que esse alcance depende do resultado da lide, conforme lecionado.

${ }^{34}$ Sobre o tema: "Confundir Jurisdição e competência com limites subjetivos da coisa julgada é, no mínimo, desconhecer a ciência do direito. Portanto, se o juiz que proferiu a sentença na ação coletiva tout court, quer verse sobre direitos difusos, quer coletivos ou individuais homogêneos, for competente, sua sentença produzirá efeitos em todo o território nacional - e também no exterior - independentemente da ilógica e inconstitucional redação dada à LACP. É de essência da ação coletiva a eficácia prevista no CDC 103". (NERY JR., Nelson; NERY, Rosa Maria Barriello de Andrade. Código de Processo Civil comentado e legislação extravagante em vigor. $7^{\mathrm{a}}$ ed. São Paulo: Revista dos Tribunais, 2003, p. 1558). No mesmo sentido, Rodolfo Mancuso assevera: "Com efeito, a questão de saber quais as pessoas atingidas pela imutabilidade do comando judicial deve ser tratada, naturalmente, sob a rubrica dos limites subjetivos desse instituto processual dito "coisa julgada" e não sob a ótica de categorias outras como a jurisdição, a competência, a organização judiciária. (...) Tudo assim reflui para que a resposta judiciária, no âmbito da jurisdição coletiva, desde que promanada de juiz competente, deve ter eficácia até onde se revele a incidência do interesse objetivado, e por modo a se estender a todos os sujeitos concernentes, e isso, mesmo em face do caráter unitário desse tipo de interesse, a exigir uma uniformidade do pronunciamento judicial". (MANCUSO, op. cit., p. 296).
} 
Revista Eletrônica de Direito Processual - REDP.

Rio de Janeiro. Ano 10. Volume 17. Número 2. Julho a Dezembro de 2016

Periódico Semestral da Pós-Graduação Stricto Sensu em Direito Processual da UERJ

Patrono: José Carlos Barbosa Moreira. ISSN 1982-7636. pp. 266-297

www.redp.uerj.br

Tornando, assim, o artigo 16 da Lei 7.347/85 inócuo e sem aplicabilidade, no que diz respeito à limitação da coisa julgada em razão da competência territorial do órgão prolator da decisão ${ }^{35}$.

Além disso, o regramento da competência territorial em sede de processo coletivo está estabelecido expressamente no artigo 93 do $\mathrm{CDC}^{36}$, como já vimos, considerado atualmente regra geral do microssistema da tutela coletiva.

Essa norma prevê que a competência para o julgamento do ilícito de âmbito regional ou nacional é da capital dos Estados ou do DF. Logo, caso a coisa julgada estivesse limitada pela competência do órgão prolator da decisão, ela sempre se daria no âmbito nacional ou regional.

Observa-se assim que, o artigo 16 da Lei 7.347/85 também se torna ineficaz, quando analisado à luz do artigo 93 do CDC, o qual traz os parâmetros da competência na tutela coletiva.

Isso posto, percebemos que faltou técnica e apreço a Teoria Geral do Processo tanto do Poder Executivo quanto posteriormente do Poder Legislativo na alteração do artigo 16 da Lei 7.347/85, no que diz respeito aos institutos da jurisdição, competência e também da coisa julgada e a extensão de seus limites subjetivos

Todavia, por incrível que pareça, ainda não pontuamos todas as impropriedades do artigo 16 da LACP, nos resta agora fazer uma análise desse regramento à luz do texto constitucional e de alguns princípios que norteiam o ordenamento jurídico e o processo civil brasileiro.

\subsection{A Inconstitucionalidade formal e material da alteração normativa e sua ofensa a diversos Princípios do Ordenamento Jurídico Brasileiro.}

Tomando como premissa maior do ordenamento jurídico brasileiro a Carta Magna, podemos afirmar, primeiramente, que a alteração normativa não respeitou o devido processo legislativo. Isso porque, não foi observado o requisito da urgência imprescindível

\footnotetext{
${ }^{35}$ Grande parte da doutrina pátria reconhece tal improbidade: MAZZILI, op. cit., p. 248-249; DIDIER JR.: ZANETI JR., op. cit., p. 132-133; RODRIGUES, op. cit., p. 282.

36 "Art. 93. Ressalvada a competência da Justiça Federal, é competente para a causa a justiça local: I - no foro do lugar onde ocorreu ou deva ocorrer o dano, quando de âmbito local; II - no foro da Capital do Estado ou no do Distrito Federal, para os danos de âmbito nacional ou regional, aplicando-se as regras do Código de Processo Civil aos casos de competência concorrente".
} 
Revista Eletrônica de Direito Processual - REDP.

Rio de Janeiro. Ano 10. Volume 17. Número 2. Julho a Dezembro de 2016

Periódico Semestral da Pós-Graduação Stricto Sensu em Direito Processual da UERJ

Patrono: José Carlos Barbosa Moreira. ISSN 1982-7636. pp. 266-297

www.redp.uerj.br

para edição de medidas provisórias (conforme artigo 62 da CF, na sua redação anterior a EC $32 / 2001^{37}$ ).

Como leciona Hugo Nigro Mazzili ${ }^{38}$, alterou-se uma sistemática que já estava em pleno vigor desde 1985 (art. 16 da LACP). Logo, possível alteração deveria ter sido feita por intermédio do processo legislativo ordinário ou por meio de Projeto de Lei proposto pelo Poder Executivo ou pelo Congresso Nacional. Não haveria urgência por parte do Poder Executivo na alteração do dispositivo.

Assim, mesmo que a Medida Provisória 1.570/97 tenha sido posteriormente convertida na Lei 9.494/97, ela ingressou no ordenamento jurídico brasileiro eivada com uma inconstitucionalidade formal, por não ter respeitado um dos critérios autorizadores para edição de uma Medida Provisória.

Ainda analisando o artigo 16 da LACP à luz da Constituição Federal, é evidente que a limitação subjetiva da coisa julgada à competência do órgão prolator da sentença é uma afronta aos princípios constitucionais da igualdade e do acesso à jurisdição ${ }^{39}$.

O princípio da isonomia, previsto no artigo $5^{\circ}$, caput, da Constituição Federal, pretende dar tratamento igualitário a todos os brasileiros sem distinção. Esse preceito fundamental foi ofendido com a alteração normativa, pois, torna-se possível que existam diferentes tratamentos processuais em uma mesma situação jurídica, como é o caso das demandas que tutelam os direitos transindividuais.

Caso a coisa julgada ficasse limitada à competência do órgão prolator, tornar-se-ia possível que um dos titulares de um determinado direito coletivo estivesse em local que não foi alcançado pela autoridade da coisa julgada de uma sentença em ação coletiva " $X$ ". Diante dessa situação, poderia ocorrer a propositura de outra ação coletiva "Y" nessa localidade, com a possibilidade de resultado diverso daquele ocorrido na ação coletiva "X".

Assim, de maneira reflexa estaríamos comprometendo também o princípio da segurança jurídica, considerado como basilar em um Estado Democrático de Direito e que pretende dar concretude e unidade a um ordenamento jurídico.

\footnotetext{
${ }^{37}$ Antiga Redação do artigo 62 da Constituição Federal: "Art. 62. Em caso de relevância e urgência, o Presidente da República poderá adotar medidas provisórias, com força de lei, devendo submetê-las de imediato ao Congresso Nacional, que, estando em recesso, será convocado extraordinariamente para se reunir no prazo de cinco dias".

38 MAZZILI, op. cit., p. 527.

${ }^{39}$ DIDIER JR.; ZANETI JR., op. cit., p. 131.
} 
Revista Eletrônica de Direito Processual - REDP.

Rio de Janeiro. Ano 10. Volume 17. Número 2. Julho a Dezembro de 2016

Periódico Semestral da Pós-Graduação Stricto Sensu em Direito Processual da UERJ

Patrono: José Carlos Barbosa Moreira. ISSN 1982-7636. pp. 266-297 www.redp.uerj.br

Tal norma implícita do ordenamento estaria ameaçada, pois como vimos, tornaríamos muito grandes as chances de ocorrerem conflitos práticos diante de uma mesma situação, o que é inaceitável.

Outrossim, também violou-se o princípio da economia processual, o qual determina que se obtenha o máximo de efetividade e atuação do direito com o mínimo de emprego possível da atividade jurisdicional do Estado ${ }^{40}$.

O cânone não foi respeitado, já que a regra do artigo 16 da Lei 7.347/85 possibilitaria um sem número de ações coletivas em diversas localidades. Tornando a efetivação da tutela de determinado direito coletivo demorada, sendo ainda dispendioso para máquina judiciária.

Quanto ao princípio do acesso à justiça, previsto no artigo $5^{\circ}$, inciso XXXV da Carta Magna pátria, devemos entender primeiramente que ocorreu em 1988 a constitucionalização da tutela coletiva ${ }^{41}$, isso fez com que a garantia constitucional da inafastabilidade da função jurisdicional ganhasse novos contornos.

Agora, a não exclusão da apreciação do Judiciário de lesão ou ameaça a qualquer direito, estende-se tanto para os de natureza individual quanto para os meta-individuais. Protegendo-se as demandas individuais e coletivas.

Como resultado disso, tornam-se inconstitucionais quaisquer tentativas de ingurgitamento ao sistema de funcionalização da tutela coletiva ${ }^{42}$.

Portanto, fica claro que o artigo 16 da Lei 7.347/85, com sua atual redação, apresenta-se como um obstáculo a tutela coletiva, pois, tenta restringir a eficácia de decisões que tutelam direitos originariamente indivisíveis.

Além disso, o dispositivo também acaba por restringir o acesso à justiça via tutela individual quando estamos diante ações coletivas referentes a direito difusos e coletivos.

Nestas ações como sabemos, vigora a coisa julgada in utilibus, nas quais a sentença é genérica, devendo haver a liquidação e execução dos danos individuais sofridos,

\footnotetext{
${ }^{40}$ CINTRA; GRINOVER; DINAMARCO, op. cit., p. 79.

${ }^{41}$ A Constituição Federal trouxe em diversas passagens proteção à tutela coletiva, vejamos: reconhecimento do direito consumidor no artigo $5^{\circ}$, inciso XXXV da CF; proteção ao meio ambiente ecologicamente correto no artigo 226 da CF; previsão da ação civil pública no artigo 129 , III da CF e da ação popular no artigo $5^{\circ}$, inciso LXXIII da CF.

${ }^{42}$ VENTURI, Elton. Processo Civil Coletivo. São Paulo: Malheiros Editores, 2007, p. 428-430. No mesmo sentido: DANTAS, Marcelo Buzaglo. Ação Civil Pública e Meio Ambiente. São Paulo: Editora Saraiva, 2009, p. 275.
} 
Revista Eletrônica de Direito Processual - REDP.

Rio de Janeiro. Ano 10. Volume 17. Número 2. Julho a Dezembro de 2016

Periódico Semestral da Pós-Graduação Stricto Sensu em Direito Processual da UERJ

Patrono: José Carlos Barbosa Moreira. ISSN 1982-7636. pp. 266-297

www.redp.uerj.br

conforme previsto no artigo 103, parágrafo $3^{\circ}$ do CDC. Estaríamos mesmo que de maneira reflexa prejudicando o direito individual das vítimas e de seus antecessores ${ }^{43}$.

Diante de todo o exposto podemos afirmar que além de ser inconstitucional formalmente o artigo 16 da LACP é ainda inconstitucional materialmente.

Pois, desrespeita os princípios constitucionais explícitos da isonomia (artigo $5^{\circ}$, caput da $\mathrm{CF}$ ) e do acesso à justiça (artigo $5^{\circ}$, inciso XXXV da $\mathrm{CF}$ ), mas não só esses, vindo a afrontar também os princípios constitucionais implícitos da segurança jurídica e da economia processual.

Após todo o exposto, finalizamos o diagnóstico de todas as impropriedades presentes nesse infeliz regramento ordinário. Realizaremos a seguir um breve relato sobre o histórico do posicionamento jurisprudencial a respeito do tema, analisando posteriormente um recente julgado do STJ à luz da teoria do julgamento-alerta.

\section{Uma possível futura mudança do entendimento por parte do STJ à luz da} Teoria do Julgamento-Alerta.

\subsection{Breve Histórico do Posicionamento Jurisprudencial em relação ao art. 16 da}

\section{Lei 7.437/85.}

A primeira importante manifestação dos Tribunais Superiores quanto ao art. 16 da LACP, ocorreu por meio da ADin 1.576-1/DF, a qual foi proposta pelo Partido Liberal objetivando a declaração de inconstitucionalidade da Medida Provisória 1.570/97 (convertida na Lei 9.494/97).

No julgamento da referida ADin ${ }^{44}$, o Pleno do Supremo Tribunal Federal deferiu em parte a medida liminar pleiteada - suspendendo a vigência do art. $2^{\circ}$ da MP 1.570/97 e a indeferiu quanto aos artigos $1^{\circ}$ e $3^{\circ}$.

Como sabemos, a alteração do artigo 16 da Lei da LACP foi feita pelo artigo $3^{\circ}$ da referida Medida Provisória. Naquele momento, portanto, o STF posicionou-se em sentido contrário a inconstitucionalidade do dispositivo. Posteriormente, a ADIn foi julgada prejudicada por falta de aditamento, decorrendo o prazo, sem interposição do recurso.

\footnotetext{
${ }^{43}$ VENTURI, op. cit., p. 428-430.

${ }^{44}$ STF, Pleno, ADIn 1.576-1/DF, rel. Ministro Marco Aurélio, julgamento 16.04.1997, DJU 24.04.1997, p. 14.914.
} 
Revista Eletrônica de Direito Processual - REDP.

Rio de Janeiro. Ano 10. Volume 17. Número 2. Julho a Dezembro de 2016

Periódico Semestral da Pós-Graduação Stricto Sensu em Direito Processual da UERJ

Patrono: José Carlos Barbosa Moreira. ISSN 1982-7636. pp. 266-297

www.redp.uerj.br

Merece ser destacado nesse ponto, o voto do ministro relator da ADIn, Marco Aurélio, o qual votou pelo indeferimento da medida liminar do artigo $3^{\circ}$ da MP 1.570/97:

“A alteração do artigo 16 ocorreu à conta da necessidade de explicitar-se a eficácia erga omnes da sentença proferida na ação civil pública. Entendo que o artigo 16 da Lei 7.347/85, harmônico com o sistema judiciário pátrio, jungia, mesmo na redação primitiva, a coisa julgada erga omnes da sentença civil à área de atuação do órgão que viesse a prolata-la. A alusão à eficácia erga omnes sempre esteve ligada à ultrapassagem dos limites subjetivos da ação, tendo em conta até mesmo o interesse em jogo - difuso ou coletivo - não alcançando, portanto, situações concretas, quer sob o ângulo objetivo, quer subjetivo, notadas além das fronteiras fixadoras do juízo. Por isso, tenho a mudança de redação como pedagógica, a revelar o surgimento de efeitos erga omnes na área de atuação do Juízo e, portanto, o respeito à competência geográfica delimitada pelas leis de regência. Isso não implica esvaziamento da ação civil pública nem, tampouco, ingerência indevida do Poder Executivo no Judiciário" (STF, Pleno, ADIn 1.576-1/DF, rel. Ministro Marco Aurélio, j. 16.04.1997, DJU 24.04.1997, p. 14.914).

Mesmo diante das inúmeras e sucessivas críticas da doutrina brasileira ao artigo, prevaleceu o entendimento na jurisprudência pátria, principalmente no STJ, pela plena eficácia e aplicabilidade do referido dispositivo. Ficando a coisa julgada coletiva limitada à competência territorial do órgão julgador ${ }^{45}$.

Após algum tempo, a Corte Especial com o intuito de uniformizar o entendimento a respeito do tema, proferiu decisões, em sede de embargos de divergência, também dando aplicabilidade ao referido dispositivo: STJ, EREsp 293.407/SP, Rel. Min. João Otávio de Noronha, DJ de 1/8/2006 e STJ, EREsp 411.529/SP, 2a seção, j. 10.03.2010, rel. Min. Fernando Gonçalves, Dje 24.03.2010.

\footnotetext{
${ }^{45}$ Podemos apontar como exemplos os seguintes julgados: STJ, $1^{\text {a }}$ T., Resp $\mathrm{n}^{\circ}$ 665.947, rel. Min. José Delgado, j. 02.12.2004, publicado no DJ de 12.02.2005 e STJ, $1^{\text {a }}$ T., Resp n ${ }^{\circ}$ 625.996, rel. p/ acórdão Teori Zazvascki, j. 13.03/2005, publicado no DJ de 02.05.2005.
} 
Revista Eletrônica de Direito Processual - REDP.

Rio de Janeiro. Ano 10. Volume 17. Número 2. Julho a Dezembro de 2016

Periódico Semestral da Pós-Graduação Stricto Sensu em Direito Processual da UERJ

Patrono: José Carlos Barbosa Moreira. ISSN 1982-7636. pp. 266-297

www.redp.uerj.br

O entendimento foi mantido por muito tempo, até que no ano de 2011, no julgamento do Recurso Especial $n^{\circ} 1.243 .887 / P R$ o STJ balançou a jurisprudência dada como consolidada.

Seguindo o louvável voto do Min. Relator Luiz Felipe Salomão ${ }^{46}$ e atendendo aos conclames de quase toda a doutrina nacional, a Corte Especial reconheceu que os efeitos da sentença em sede de direitos metaindividuais não estão circunscritos à competência territorial do órgão prolator, vejamos:

“DIREITO PROCESSUAL. RECURSO REPRESENTATIVO DE CONTROVÉRSIA (ART. 543-C, CPC). DIREITOS METAINDIVIDUAIS. AÇÃO CIVIL PÚBLICA. APADECO XBANESTADO. EXPURGOS INFLACIONÁRIOS. EXECUÇÃO/LIQUIDAÇÃO INDIVIDUAL.FORO COMPETENTE. ALCANCE OBJETIVO E SUBJETIVO DOS EFEITOS DASENTENÇA COLETIVA. LIMITAÇÃO TERRITORIAL. IMPROPRIEDADE. REVISÃOJURISPRUDENCIAL. LIMITAÇÃO AOS ASSOCIADOS. INVIABILIDADE. OFENSA ÀCOISA JULGADA. 1. Para efeitos do art. 543-C do CPC:1.1. A liquidação e a execução individual de sentença genérica proferida em ação civil coletiva pode ser ajuizada no foro do domicílio do beneficiário, porquanto os efeitos e a eficácia da sentença não estão circunscritos a lindes geográficos, mas aos limites objetivos e subjetivos do que foi decidido, levando-se em conta, para tanto, sempre a extensão do dano e a qualidade dos interesses metaindividuais postos em juízo (arts. 468, 472 e 474,CPC e 93 e 103, CDC [...] .3. Recurso especial parcialmente conhecido e não provido.(STJ - REsp: 1243887 PR 2011/00534155, Relator: Ministro LUIS FELIPE SALOMÃO, Data de

\footnotetext{
${ }^{46}$ No teor de seu voto o Min. Luiz Felipe Salomão conclui: “A antiga jurisprudência do STJ, segundo a qual "a eficácia erga omnes circunscreve-se aos limites da jurisdição do tribunal competente para julgar o recurso ordinário" (REsp 293.407/SP, Quarta Turma, confirmado nos EREsp. n. 293.407/SP, Corte Especial), em hora mais que ansiada pela sociedade e pela comunidade jurídica, deve ser revista para atender ao real e legítimo propósito das ações coletivas, que é viabilizar um comando judicial célere e uniforme - em atenção à extensão do interesse metaindividual objetivado na lide".
} 
Revista Eletrônica de Direito Processual - REDP.

Rio de Janeiro. Ano 10. Volume 17. Número 2. Julho a Dezembro de 2016

Periódico Semestral da Pós-Graduação Stricto Sensu em Direito Processual da UERJ

Patrono: José Carlos Barbosa Moreira. ISSN 1982-7636. pp. 266-297

www.redp.uerj.br

Julgamento: 19/10/2011, CE - CORTE ESPECIAL, Data de

Publicação: DJe 12/12/2011)". (grifo nosso).

A partir desse decisum esperava-se que a Jurisprudência consolida-se tal entendimento. Entretanto, ressalvados alguns precedentes que foram capitaneados pela Min. Nancy Andrighi ${ }^{47}$, o STJ manteve aplicabilidade ao artigo 16 da Lei da LACP $^{48}$.

Dessa forma, atualmente, podemos afirmar que predomina no STJ o entendimento quanto à limitação da coisa julgada em sede de ação civil pública à competência do órgão prolator da sentença, vejamos alguns arestos:

“[...] 6. Nos termos da jurisprudência do STJ, a sentença na ação civil pública faz coisa julgada erga omnes nos limites da competência territorial do órgão prolator, nos termos do art. 16 da Lei $\mathrm{n}^{\circ} 7.347 / 85$, com a nova redação conferida pela Lei $\mathrm{n}^{\circ}$ 9.494/97.7. Se o órgão prolator da decisão é o Tribunal de Justiça do Estado do Rio Grande do Sul, infere-se que o acórdão tem eficácia em toda a extensão territorial daquela unidade da Federação". (STJ, REsp 1304953/RS, Rel. Ministra Nancy

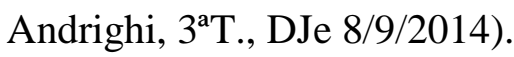

"[...] foi pacificado pela Corte Especial o entendimento de que a sentença proferida em Ação Civil Pública fará coisa julgada erga omnes nos limites da competência territorial do órgão prolator da decisão, nos termos do art. 16 da Lei 7.347/85, alterado pela Lei 9.494/97. Assim, incabível a determinação do requerido estudo técnico com o intuito de disponibilizar o fármaco pelo SUS, com abrangência nacional, pois estar-se-ia violando o limite territorial do juízo a quo". (STJ, AgRg no REsp 1353720/SC, Rel. Ministro Herman Benjamin, 2'a T, DJe 25/9/2014)".

\footnotetext{
${ }^{47}$ São eles: STJ, REsp 1.243.386/RS, $3^{\text {a }}$ T., j. 12.06.2012, v.u, rel. Min. Nancy Andrighi, DJe 26.06.2012 e STJ, AgRg no REsp 1.326.477/DF, $3^{\text {a }}$ T., j. 06.09.2012, v.u, rel. Min. Nancy Andrighi, DJ 13.09.2012.

${ }^{48}$ Nesse sentido: STJ, AgRg no REsp 1.279.061/MT, $2^{\mathrm{a}}$ T., j. 19.04.2012, v.u, rel. Min. Humberto Martins, DJe 26.04.2012 e STJ, AgRg no REsp 1.338.029/PR, 2 ${ }^{\mathrm{a}}$ T., j. 13.11.2012, v.u, rel. Min. Mauro Campbell Marques, DJe 21.11.2012.
} 
Revista Eletrônica de Direito Processual - REDP.

Rio de Janeiro. Ano 10. Volume 17. Número 2. Julho a Dezembro de 2016

Periódico Semestral da Pós-Graduação Stricto Sensu em Direito Processual da UERJ

Patrono: José Carlos Barbosa Moreira. ISSN 1982-7636. pp. 266-297

www.redp.uerj.br

Entretanto, vale ser ressaltado que está pendente o julgamento pela Corte Especial dos Embargos de Divergência no REsp n ${ }^{\circ}$ 1.243.386/RS, nos quais se discutirá novamente a aplicabilidade do artigo 16 da Lei 7.347/85. Sendo assim, ocorrerá um nove embate quanto a temática, esperando-se que a matéria seja, de uma vez por todas, uniformizada e pacificada.

Nessa esteira, um recente julgado - REsp 1.114.035/PR - que foi inclusive veiculado no Informativo $\mathrm{n}^{\circ} 0552$ do STJ, pode vir a demonstrar uma possível mudança no entendimento da Corte quando do julgamento dos EREsp. $\mathrm{n}^{\circ} 1.243 .386 / \mathrm{RS}$.

\subsection{A Técnica do Julgamento-Alerta nos países de civil law.}

Antes de realizar-se a análise do REsp. 1.114.035/PR à luz da técnica do Julgamento-Alerta, é imprescindível que teçamos alguns comentários sobre esta com intuito de melhor compreende-la, já que ainda não é muito conhecida no espaço jurídico brasileiro.

Primeiramente, devemos destacar que essa teoria foi capitaneada no Brasil pelo jurista Antônio do Passo Cabral e tem suas origens nos países de common law, nos quais a força dos precedentes jurisprudenciais é imensa, diferentemente do que ocorre nos ordenamentos jurídicos de civil law $^{49}$.

Todavia, esse costume vem se alterando em países de civil law, como é o caso do Brasil. Após advindo da Constituição Federal de 1988, os Tribunais Superiores ganharam destaque. Atualmente, o STF e o STJ tem a função de uniformizar a jurisprudência pátria, o que deu força aos precedentes judiciários dentro do ordenamento jurídico brasileiro ${ }^{50}$.

\footnotetext{
${ }^{49}$ Afirmamos isso, pois, nos países de common law, o direito tem como sua principal fonte os costumes, ou seja, adotando-se a chamada técnica da stare decisis (técnica dos precedentes), na grande maioria das vezes as decisões judiciais serão tomadas tendo como base decisums anteriores da mesma natureza (OLIVEIRA, Ana Carolina Borges. Diferenças e semelhanças entre os sistemas da civil law e da common law. Constituição, Economia e Desenvolvimento: Revista da Academia Brasileira de Direito Constitucional. Vol. 6, n. 10, p. 44-45, Jan-Jun/2014). Já nos países de civil law, o direito é constituído e regulado, principalmente, por regras de conduta, as quais serão abstratas e se aplicarão ao maior número de casos hipotéticos possíveis, para que assim, se possa regular o convívio em sociedade (Ibidem, p. 46/47). Fica evidente que os precedentes tem um grau de importância muito maior nos países de common law do que nos países de civil law, isso porque, é a utilização da técnica dos precedentes que dá segurança jurídica e dinâmica àqueles ordenamentos jurídicos.

${ }^{50}$ CABRAL, Antônio do Passo. A Técnica do Julgamento-Alerta na mudança de Jurisprudência Consolidada. Revista de Processo. vol. 221, p.14, Jul/2013.
} 
Revista Eletrônica de Direito Processual - REDP.

Rio de Janeiro. Ano 10. Volume 17. Número 2. Julho a Dezembro de 2016

Periódico Semestral da Pós-Graduação Stricto Sensu em Direito Processual da UERJ

Patrono: José Carlos Barbosa Moreira. ISSN 1982-7636. pp. 266-297

www.redp.uerj.br

Inclusive com a entrada em vigor do Novo CPC essa realidade, no ordenamento

jurídico brasileiro, considerado como um sistema predominantemente de civil law, irá ser alterada, isso porque, os procedentes terão força de lei, ou seja, deverão ser seguidos e considerados pelo julgador quando da atividade cognoscitiva-decisória ${ }^{51}$.

Tais tribunais ao assumirem esse papel acabam por influenciar os padrões de comportamento tanto dos operadores do direito, quanto da sociedade como um todo. Espera-se que a partir de um determinado caso concreto o Judiciário adote certo posicionamento, devido aos precedentes jurisprudenciais dos Tribunais Superiores ${ }^{52}$.

Ganha destaque, nesse contexto dos precedentes, a figura da jurisprudência consolidada, que podemos conceituar, nos países de civil law, como um entendimento predominante a respeito de uma temática ou caso concreto criado a partir de uma série de decisões dos Tribunais Superiores ao longo do tempo.

Ressalta-se que uma jurisprudência consolidada sempre está aberta a mudança. É comum, não só nas ciências naturais, mas também nas ciências jurídicas, que um entendimento predominante seja alterado com o decorrer do tempo, isso acontece devido ao natural desenvolvimento e evolução do direito e também da sociedade como um todo ${ }^{53}$.

Diante dessa possibilidade de mudança de uma jurisprudência consolidada surge a figura da técnica de Julgamento-Alerta, considerada como um mecanismo de proteção da continuidade jurídica na mudança de jurisprudência.

Assim, podemos conceituar o Julgamento-Alerta como um "anúncio público" da possível revisão de uma jurisprudência consolidada ${ }^{54}$, ou seja, trata-se de uma decisão que

51 DIDIER JR., Fredie; BRAGA, Paulo Sarno; OLIVEIRA, Rafael Alexandria de. Curso de Direito Processual Civil. Salvador: Juspodivm, 2015, v. 2, p. 473-485. No mesmo sentido: ZANETI JR., Hermes. $O$ Valor Vinculante dos Precedentes. Salvador: Juspodivm, 2015, p. 359-384.

${ }^{52}$ Nessa esteira, esses precedentes jurisprudências acabam por contemplar e garantir segurança jurídica ao ordenamento jurídico, como aponta Antônio do Passo Cabral: "Em razão dessas tendências, as preocupações com a segurança jurídica, que incorpora elementos de certeza, cognoscibilidade e duração da jurisprudência solidificada, é hoje um tema em pauta também nos estudos processuais sobre a estabilidade do entendimento consolidado nos tribunais. Sem embargo, na atualidade, a reboque da crescente importância da jurisprudência consolidada nos comportamentos humanos mesmo nos países de civil law, faz-se necessário que os precedentes que refletem uma conclusão pretoriana estável perdurem, bem assim que as mudanças de jurisprudência sejam operadas de maneira responsável, controlável, e com considerações a respeito da segurança jurídica no tempo." (CABRAL, op. cit., p.14). Nesse sentido: MARINONI, Luiz Guilherme. Precedentes Obrigatórios. São Paulo: Revistas dos Tribunais, 2013, p. 118-121.

${ }^{53}$ CABRAL, op. cit., p.14-15.

${ }^{54}$ Ibidem , p. 21. 
Revista Eletrônica de Direito Processual - REDP.

Rio de Janeiro. Ano 10. Volume 17. Número 2. Julho a Dezembro de 2016

Periódico Semestral da Pós-Graduação Stricto Sensu em Direito Processual da UERJ

Patrono: José Carlos Barbosa Moreira. ISSN 1982-7636. pp. 266-297

www.redp.uerj.br

veicula a possibilidade de um Tribunal Superior estar realizando uma revisão de um entendimento, até então, considerado como consolidado ${ }^{55}$.

Isso não quer dizer que obrigatoriamente deva ocorrer uma mudança na jurisprudência consolidada, como vimos, trata-se de uma possibilidade de alteração, a qual pode vir ou não a acontecer em um futuro próximo.

Essa técnica influi nos interesses individuais, já que informa aos particulares quanto à relativa insegurança devido a possibilidade de mudança, fazendo com que se preparem e deixem de praticar condutas baseadas na jurisprudência consolidada, a qual poderá ser alterada.

Além disso, incide também nos interesses públicos, garantindo segurança jurídica ao ordenamento jurídico sem deixar de lado a continuidade jurídica, fomentando-se alterações com o menor impacto possível.

Uma decisão-alerta possui alguns atributos formais, os quais deverão ser enumerados aqui para que posteriormente possamos realizar o perfeito encaixe das características ao REsp 1.114.035/PR.

Temos como atributos de um julgamento-alerta: 1) A grande amplitude da publicidade que o aviso público da possível mudança de jurisprudência tem;2) $\mathrm{O}$ apontamento de qual regra ou instituto que poderá ter sua interpretação ou aplicação revista; 3) O destaque para os novos fundamentos utilizados de maneira clara e direita; 4) A decisão-alerta deve vir, sempre que possível, no voto condutor do julgamento; 5) A decisão deve ser proferida, de preferência, por Tribunais Superiores ${ }^{56}$.

Diante disso, após compreender a teoria, o conceito do julgamento-alerta e quais são suas características, estamos aptos a analisar o referido julgado.

\subsection{A análise do REsp $n^{\circ}$ 1.114.035/PR à luz da técnica do julgamento-alerta e a possibilidade/necessidade de futura mudança na Jurisprudência do STJ quanto a aplicabilidade do artigo 16 da Lei 7.347/85.}

\footnotetext{
55 Do exposto, podemos concluir que a técnica do julgamento-alerta é de suma importância para o sistema dos precedentes. Isso porque, o julgamento-alerta antecedendo o overrruling ou overrreading (formas superação de um antigo precedente) faz um aviso público de que tal mudança poderá acontecer em um futuro próximo, garantindo a continuidade sem deixar de lado a segurança jurídica. Em outras palavras podemos dizer que a técnica do julgamento-alerta garante que a mudança no direito seja feita com consistência, de maneira ponderada e pública, assegurando a estabilidade do ordenamento jurídico.

${ }^{56}$ CABRAL, op. cit., p. 24-25.
} 
Revista Eletrônica de Direito Processual - REDP.

Rio de Janeiro. Ano 10. Volume 17. Número 2. Julho a Dezembro de 2016

Periódico Semestral da Pós-Graduação Stricto Sensu em Direito Processual da UERJ

Patrono: José Carlos Barbosa Moreira. ISSN 1982-7636. pp. 266-297

www.redp.uerj.br

Assim, tentando demonstrar de que se trata de uma decisão-alerta, no que diz respeito à possível mudança de jurisprudência pelo STJ no julgamento do EREsp $\mathrm{n}^{\mathrm{o}}$ 1.243.386/RS, iremos realizar uma análise do REsp 1.114.035/PR ${ }^{57}$, amoldando-o às características formais de uma decisão-alerta.

Primeiramente, é importante salientar a presença de jurisprudência consolidada do STJ no que diz respeito a plena aplicabilidade do artigo 16 da Lei 7.347/85. Como viu-se no histórico jurisprudencial deste Tribunal, prevalece por muito tempo o entendimento de que a coisa julgada coletiva fica limitada pela competência territorial do órgão prolator da decisão.

Na sequência, percebe-se que o julgado foi proferido pelo Superior Tribunal de Justiça, logo, está preenchido o requisito de que o julgamento tenha sido proferido por um Tribunal Superior para ser considerada uma decisão-alerta.

Além disso, é sabido que o STJ dá publicidade a todas suas decisões, inclusive tais julgamentos podem ser acessados por qualquer cidadão por meio da internet.

Outrossim, como dito, o REsp 1.114.035/PR foi assunto tratado no Informativo $\mathrm{n}^{\mathrm{o}}$ 0552 do STJ, distribuído gratuitamente via e-mail por sistema push. Dessa forma, também está presente o atributo da grande amplitude da publicidade no referido julgado.

Outra característica que se faz presente no julgado é que a decisão-alerta venha no voto condutor do julgamento, in casu, o voto foi proferido pelo Min. João Otávio de Noronha ${ }^{58}$.

Seguindo, cabe demonstrar que no conteúdo do decisum faz-se referência expressa de qual regra poderá ter sua interpretação revista. No caso em questão, a aplicabilidade do artigo 16 da Lei $n^{\circ} 7.347 / 85$ no que diz respeito aos limites subjetivos da coisa julgada, vejamos:

"[...] Finalmente quanto ao alcance nacional dos efeitos erga omnes atribuídos a sentença civil [...] a matéria que aqui se debate é o

\footnotetext{
57 Trata-se de Recurso Especial interposto pela Caixa Econômica contra acórdão proferido pelo TRF $4^{\mathrm{a}}$ Região de Relatória da Des. Marga Inge Barth Tessler, o qual negou provimento à apelação interposta pela CEF. Sustenta-se que nem a sentença e nem o acórdão da ação civil pública poderiam ter eficácia em todo o território nacional, sob pena de ofensa ao artigo 16 da Lei 7.347/85.

${ }^{58}$ Consta na certidão de julgamento: "[...] Prosseguindo no julgamento, após voto-vista do Sr. Ministro João Otávio de Noronha, divergindo do Sr. Ministro Relator, a Terceira Turma, por maioria, deu provimento parcial ao recurso especial, nos termos do voto do Sr. Ministro João Otávio de Noronha".
} 
Revista Eletrônica de Direito Processual - REDP.

Rio de Janeiro. Ano 10. Volume 17. Número 2. Julho a Dezembro de 2016

Periódico Semestral da Pós-Graduação Stricto Sensu em Direito Processual da UERJ

Patrono: José Carlos Barbosa Moreira. ISSN 1982-7636. pp. 266-297

www.redp.uerj.br

alcance da eficácia subjetiva da sentença coletiva" (STJ, REsp

1.114.035/PR, $2^{\mathrm{a}}$ T., Rel. para acórdão Min. João Otávio de

Noronha, j. 7.10.2014).

Finalmente, chega-se à característica mais controversa e de mais difícil demonstração do instituto da decisão-alerta, qual seja, a presença e o destaque dos novos fundamentos utilizados na futura possível mudança no entendimento consolidado.

Nessa esteira, destacar-se-á, no REsp no 1.114.035/PR, que o voto do Min. João Otávio de Noronha deixa clara a ineficácia do dispositivo no que diz respeito a confusão entre os institutos da competência e dos limites subjetivos da coisa julgada. Aponta também que devido ao caráter indivisível dos direitos difusos e coletivos strictu sensu não há como cindir os efeitos da sentença civil, vejamos:

"[...] No que tange à ineficácia do dispositivo, começo por registar que, além das impropriedades terminológicas do artigo em questão, o que o legislador pretendeu regular foi o alcance subjetivo da sentença civil, vale dizer, a identificação de quem são os sujeitos a quem se estendem os efeitos da coisa julgada. Isso nada tem a ver com a eficácia da sentença civil fora dos limites de jurisdição do órgão prolator. Com efeito, qualquer sentença, seja proferida em processo de natureza coletiva ou individual, possui eficácia em todo o território nacional relativamente às partes a ela vinculadas."

\section{“[...] Penso que o caráter indivisível dos direitos difusos e} coletivos strictu sensu conduz ao impedimento prático, e mesmo lógico, de qualquer interpretação voltada a cindir os efeitos da sentença civil [...] Com efeito, por envolverem bens indivisíveis, cujo o gozo ou utilização não é viável de forma individualizada, não há como sustentar, por exemplo, que uma sentença que determine a uma empresa que retire do mercado determinado produto considerado lesivo à saúde dos consumidores possa beneficiar apenas os consumidores de determinada região. A retirada do produto do mercado fatalmente beneficiará, de forma indistinta, todo o universo de consumidores que poderiam vir a consumi-lo, onde quer que se encontrem." (STJ, REsp 
Revista Eletrônica de Direito Processual - REDP.

Rio de Janeiro. Ano 10. Volume 17. Número 2. Julho a Dezembro de 2016

Periódico Semestral da Pós-Graduação Stricto Sensu em Direito Processual da UERJ

Patrono: José Carlos Barbosa Moreira. ISSN 1982-7636. pp. 266-297 www.redp.uerj.br

1.114.035/PR, 2 $2^{\mathrm{a}}$ T., Rel. para acórdão Min. João Otávio de Noronha, j. 7.10.2014) (grifo nosso).

Entretanto, mesmo reconhecendo as impropriedades do artigo 16 da Lei $\mathrm{n}^{\mathrm{o}} 7347 / 85$, o ministro declarou que o artigo 16 está em pleno vigor. Foi além, ditando que tais impropriedades, ainda que indesejáveis, não se aplicariam aos direitos individuais homogêneos, logo, o efeito erga omnes da sentença estaria limitado pelo competência do órgão prolator da sentença, vejamos:

“[...] Como salientado anteriormente, estando em pleno vigor o disposto no art. 16 da lei da Ação Civil Pública, cabe ao aplicador do Direito encontrar, com base numa interpretação sistêmica, uma hipótese para sua incidência".

“[...] Nesse contexto, penso que o dispositivo encontra aplicação naquelas ações civis públicas que envolvam direitos individuais homogêneos, únicos a admitir, pelo caráter divisível, a possibilidade de decisões eventualmente distintas, ainda que não desejáveis, para os diversos titulares dos direitos autônomos, embora heterogêneos".

"[...] Declarar que o efeito erga omnes da sentença civil coletiva circunscreve-se aos limites da competência territorial do órgão prolator, nos termos do artigo 16 da Lei $n^{\circ} 7.347 / 85$ " (STJ, REsp 1.114.035/PR, 2 ${ }^{\mathrm{a}}$ T., Rel. p/ acórdão Min. João Otávio de Noronha, j. 7.10.2014).

Portanto, pode-se concluir que ficou demonstrado o reconhecimento por parte do STJ da ineficácia do dispositivo no que diz respeito à indivisibilidade do objeto da tutela coletiva, pelo menos quando se tutela direitos difusos e coletivos strictu sensu. Mesmo nos casos dos direitos individuais homogêneos ficou evidente que a limitação territorial é indesejável.

Além disso, também se constatou a confusão terminológica utilizada no dispositivo normativo, o qual confundiu os institutos da competência territorial e dos limites subjetivos da coisa julgada. 
Revista Eletrônica de Direito Processual - REDP.

Rio de Janeiro. Ano 10. Volume 17. Número 2. Julho a Dezembro de 2016

Periódico Semestral da Pós-Graduação Stricto Sensu em Direito Processual da UERJ

Patrono: José Carlos Barbosa Moreira. ISSN 1982-7636. pp. 266-297

www.redp.uerj.br

Isso nos leva a crer, mesmo que de maneira não tão direta e clara, que o STJ deixou em aberto, talvez no julgamento dos EREsp n $n^{\circ} 1.243 .386 / R S$, a possibilidade de alteração no entendimento até então predominante da Corte.

Espera-se que nesse julgamento seja declarado que os limites subjetivos da coisa julgada coletiva não estão circunscritos pela competência territorial do órgão prolator da decisão.

Outro não pode ser o entendimento, pois, além das inconstitucionalidades e impropriedades terminológicas, a regra prevista no artigo 16 da Lei 7.347/85, não pode prosperar, tendo em vista, o Microssistema da Tutela Coletiva e a indivisibilidade do objeto nas demandas referentes aos direitos coletivos lato sensu. Isso tudo torna a mudança na jurisprudência do STJ mais que uma simples possibilidade, apresentando-se na verdade como uma necessidade.

\section{Conclusão.}

À guisa de conclusões, formulam-se a seguir as seguintes proposições:

Tomando como parâmetro o Microssistema da Tutela Coletiva, a coisa julgada coletiva está delimitada no artigo 103 do CDC. Sua extensão subjetiva pode ser erga omnes (nos direitos difusos e individuais homogêneos) e ultra partes (nos direito coletivos strictu sensu) a depender do direito transindividual tutelado, sempre atingindo todos os membros do grupo.

A alteração do artigo 16 da Lei $n^{0} 7.347 / 85$ feita pela MP 1.570/97 (convertida na Lei 9.494/97) que pretende limitar a coisa julgada coletiva á competência territorial do órgão prolator não pode prosperar. Isso porque, ela é inconstitucional tanto formal quanto materialmente. Além de ter confundido os conceitos de competência com os limites subjetivos da coisa julgada.

Outrossim, tal limitação seria ineficaz, tendo em vista a indivisibilidade ontológica do objeto da tutela jurisdicional coletiva, ou seja, a natureza dos direitos coletivos lato sensu não permite uma cisão da res judicata coletiva.

Atualmente, predomina no STJ o entendimento pela aplicabilidade do artigo 16 da Lei 7.347/85, ou seja, a coisa julgada estaria limitada pela competência territorial do órgão prolator da decisão em sede de ação civil pública. 
Revista Eletrônica de Direito Processual - REDP.

Rio de Janeiro. Ano 10. Volume 17. Número 2. Julho a Dezembro de 2016

Periódico Semestral da Pós-Graduação Stricto Sensu em Direito Processual da UERJ

Patrono: José Carlos Barbosa Moreira. ISSN 1982-7636. pp. 266-297

www.redp.uerj.br

Entretanto, ao analisar o REsp 1.114.035/PR à luz da técnica do julgamento-alerta, percebeu-se que o decisum pode ser apontado como uma decisão-alerta. Diante disso, o STJ poderá realizar uma futura mudança em seu entendimento predominante no julgamento dos Embargos de Divergência do REsp n ${ }^{\circ}$ 1.114.035/PR, para declarar a inaplicabilidade do artigo 16 da Lei .7347/85.

Conclui-se que tal mudança, além de possível, é necessária para que se aumente a efetividade da tutela coletiva no ordenamento jurídico brasileiro, garantindo-se um dos pilares do processo coletivo, qual seja, a solução molecularizada dos conflitos em massa.

\section{REFERÊNCIAS BIBLIOGRÁFICAS}

ALMEIDA, Gregório Assagra de. Direito Processual Coletivo Brasileiro: Um novo ramo do direito processual. São Paulo: Saraiva. 2003.

ARENHART, Sérgio Cruz; MARINONI, Luiz Guilherme. Manual do processo de Conhecimento. $3^{\mathrm{a}}$ ed. São Paulo: Revista dos Tribunais, 1995.

BUENO, Cássio Scarpinella. O Poder Público em Juízo. 2ª ed. São Paulo: Saraiva, 2003.

BRASIL. Lei $\mathrm{n}^{\mathrm{o}}$ 8.078, de 11 de setembro de 1990. Brasília, 1990. Disponível em: <http://www.planalto.gov.br/ccivil_03/leis/18078.htm>. Acesso em: 05 maio de 2015.

BRASIL. Lei $\mathrm{n}^{\mathrm{o}}$ 7.347, de julho de 1985. Brasília, 1985. Disponível em: <http://www.planalto.gov.br/ccivil_03/leis/17347compilada.htm>. Acesso em: 05 de maio de 2015.

CABRAL, Antônio do Passo. A Técnica do Julgamento-Alerta na mudança de Jurisprudência Consolidada. Revista de Processo. vol. 221, p.13, Jul/2013.

CARNELUTTI, Francesco. Diritto e processo. Nápoles: Morano, 1958.

CHIOVENDA, Giuseppe. Instituzioni di diritto processuale civile. Nápoles: Jovene, 1933.

Trad. Port. De J. Guimarães Menegale. São Paulo: Editora Saraiva, 1965.

CINTRA, Antônio Carlos de Araújo; GRINOVER, Ada Pellegrini; DINAMARCO, Cândido Rangel. Teoria Geral do Processo. 27ª ed. São Paulo: Malheiros, 2011.

COUTURE, Eduardo José. Fundamentos Del Derecho Procesal Civil. $4^{\mathrm{a}}$ Ed. Buenos Aires: BdeF, 2007. 
Revista Eletrônica de Direito Processual - REDP.

Rio de Janeiro. Ano 10. Volume 17. Número 2. Julho a Dezembro de 2016

Periódico Semestral da Pós-Graduação Stricto Sensu em Direito Processual da UERJ

Patrono: José Carlos Barbosa Moreira. ISSN 1982-7636. pp. 266-297

www.redp.uerj.br

CRUZ E TUCCI, José Rogério. Limites Subjetivos da Eficácia da Sentença e da Coisa

Julgada nas ações coletivas. Doutrinas Essenciais de Processo Civil. vol. 9, p. 645, Out/2011.

DANTAS, Marcelo Buzaglo. Ação Civil Pública e Meio Ambiente. São Paulo: Editora Saraiva, 2009.

DIDIER JR., Freddie Souza; ZANETI JR., Hermes. Curso de Direito Processual Civil. 9a ed. Salvador: JusPodivm, 2014. v. 4.

DIDIER JR., Fredie; BRAGA, Paulo Sarno; OLIVEIRA, Rafael Alexandria de. Curso de Direito Processual Civil. Salvador: Juspodivm, 2015, v. 2.

GIDI, Antônio. A Class Action como instrumento de tutela coletiva dos direitos: As ações coletivas e uma perspectiva comparada. São Paulo: Revista dos Tribunais, 2007.

Coisa Julgada e Litispendência em Ações Coletivas. São Paulo: Saraiva, 1995.

Rumo a um código de processo civil coletivo: a codificação das ações coletivas do

Brasil. Rio de Janeiro: GZ Editora. 2008.

GRINOVER, Ada Pelegrini; WATANABE, Kazuo; NERY JR., Nelson. Código de Defesa do Consumidor: comentado pelos autores do anteprojeto. $10^{\mathrm{a}}$ ed. São Paulo: Forense Universitária, 2011, vol. 1 e 2.

LENZA, Pedro. Teoria Geral da Ação Civil Pública. São Paulo: Revista dos Tribunais, 2003.

LEONEL, Ricardo de Barros. Manual do processo coletivo. São Paulo: Revista dos Tribunais, 2002.

MANCUSO, Rodolfo de Camargo. Ação Civil Pública em defesa do meio ambiente, do patrimônio cultural e dos consumidores. $8^{\text {a }}$ ed. São Paulo: Editora Revista dos Tribunais, 2002.

Manual do Consumidor em Juízo. São Paulo: Saraiva, 2004.

MAZZEI, Rodrigo Reis. A ação popular e o microssistema da tutela coletiva. In: DIDIER JR., Fredie Souza. MOUTA, José Henrique; MENDES, Aluisio Gonçalves de Castro. Tutela Jurisdicional Coletiva. Salvador: Juspodivm, 2009.

MAZZILI, Hugo Nigro. A Defesa dos Interesses Difusos em Juízo: meio ambiente, consumidor, patrimônio cultural, patrimônio público e outros interesses. $20^{\mathrm{a}}$ Ed. São Paulo: Saraiva, 2007. 
Revista Eletrônica de Direito Processual - REDP.

Rio de Janeiro. Ano 10. Volume 17. Número 2. Julho a Dezembro de 2016

Periódico Semestral da Pós-Graduação Stricto Sensu em Direito Processual da UERJ

Patrono: José Carlos Barbosa Moreira. ISSN 1982-7636. pp. 266-297

www.redp.uerj.br

MOREIRA, José Carlos Barbosa. Ações coletivas na Constituição Federal de 1988. In:

MILARÉ, Edis. A ação civil pública: após 25 anos. São Paulo: Revista dos Tribunais, 2010.

NERY JR., Nelson; NERY, Rosa Maria Barriello de Andrade. Código de Processo Civil comentado e legislação extravagante em vigor. $7^{\text {a }}$ ed. São Paulo: Revista dos Tribunais, 2003.

OLIVEIRA, Ana Carolina Borges. Diferenças e semelhanças entre os sistemas da civil law e da common law. Constituição, Economia e Desenvolvimento: Revista da Academia Brasileira de Direito Constitucional. Vol. 6, n. 10, p. 43-68, Jan-Jun/2014.

RODRIGUES, Marcelo Abelha. Ação Civil Pública e Meio Ambiente. Rio de Janeiro: Editora Forense Universitária, 2009.

; Coord. LENZA, Pedro. Direito Ambiental Esquematizado. 2a ed. São Paulo: Saraiva, 2015.

VENTURI, Elton. Processo Civil Coletivo. São Paulo: Malheiros Editores, 2007.

ZANETI JR., Hermes. O Valor Vinculante dos Precedentes. Salvador: Juspodivm, 2015.

ZAVASCKI, Teori Albino. Processo Coletivo: tutela de direitos coletivos e tutela coletiva de direitos. São Paulo: Revista dos Tribunais 2006. 